\title{
Superação da dormência e germinação in vitro de sementes de bracatinga (Mimosa scabrella Bentham)
}

\author{
Overcome dormancy and in vitro germination of seeds of \\ Mimosa scabrella Bentham
}

\author{
Felippe Côrrea da Rosa ${ }^{1}$; Lia Rejane Silveira Reiniger ${ }^{2 *}$; Diego Pascoal Golle \\ Marlove Fátima Brião Muniz'; Aline Ritter Curti ${ }^{5}$
}

\section{Resumo}

\begin{abstract}
A bracatinga, Mimosa scabrella Bentham, é uma árvore nativa do Brasil de importância ecológica e econômica, cuja produção de mudas de qualidade pode ser efetuada via cultura de tecidos. Este trabalho objetivou selecionar um método para a superação de dormência, bem como estabelecer a concentração de sais do meio nutritivo MS mais adequada para a germinação in vitro das sementes de bracatinga. Foram avaliados quatro tratamentos para superação: escarificação mecânica; imersão em água à temperatura ambiente por 24 horas; imersão em água quente $\left(80^{\circ} \mathrm{C}\right)$ por 5 minutos; e testemunha, dispostos em delineamento inteiramente casualizado, com quatro repetições de 50 sementes. Após sete dias, foi avaliada a germinação (plântulas normais), e, aos 14 dias, plântulas anormais, sementes firmes e mortas. Em um segundo ensaio, após a desinfestação e escarificação mecânica, as sementes foram cultivadas em meio nutritivo MS, em quatro concentrações de sais (1/8, 1/4, 1/2 ou integral), em delineamento inteiramente casualizado, com 25 repetições de três sementes. Aos 25 dias de cultivo, avaliou-se a porcentagem de germinação in vitro das sementes. Dentre os métodos testados para superar a dormência, a escarificação mecânica foi o mais eficiente. A máxima germinação in vitro foi observada no meio 1/4 MS. A escarificação mecânica com lixa proporciona a maior taxa de germinação, enquanto a máxima germinação in vitro é observada utilizando-se a concentração de sais do meio MS a 1/4.
\end{abstract}

Palavras-chave: Escarificação mecânica, espécie florestal, meios nutritivos

\begin{abstract}
Mimosa scabrella Bentham is a tree native to Brazil of ecological and economic importance, whose production of quality seedlings can be performed via tissue culture. This work aimed to select a method to overcome dormancy and to establish the concentration of salts in the MS nutritive medium best suited for in vitro germination of seeds of M. scabrella. Were evaluated four treatments to overcome dormancy: mechanical scarification; immersion in water at room temperature for 24 hours; immersion in hot water $\left(80^{\circ} \mathrm{C}\right)$ for 5 minutes, and control, arranged in a randomized design with four replicates of 50 seeds. After seven days, we evaluated the germination and at 14 days, abnormal seedlings, dead and firm seeds. In one the second assay, after disinfestation and mechanical scarification, seeds were cultivated in MS nutritive medium in four concentrations of salts, according to treatment: 1/8, 1/4, 1/2 or full (100\%), arranged in completely randomized design with 25 replicates, each with three seeds. At 25 days of culture, we evaluated the in vitro germination of seeds. Among the tested methods to overcome
\end{abstract}

1 Eng ${ }^{\mathrm{o}}$ Florestal, MSc. Engenharia Florestal, Dept ${ }^{\mathrm{o}}$ Fitotecnia, Universidade Federal de Santa Maria, UFSM, Santa Maria. E-mail: felippe_florestal@yahoo.com.br

2 Eng ${ }^{\mathrm{a}}$ Agr ${ }^{\mathrm{a}}$, Prof ${ }^{\mathrm{a}}$ Dr $^{\mathrm{a}}$ Associada do Dept ${ }^{\mathrm{o}}$ Fitotecnia, UFSM. E-mail: liarsr@ufsm.br

3 Biól., Prof. Dr. do Centro de Ciências da saúde, Universidade de Cruz Alta, UNICRUZ. E-mail: diego.golle@gmail.com

4 Enga Agr $^{\mathrm{a}}$, Prof ${ }^{\mathrm{a}} \mathrm{Dr}^{\mathrm{a}}$ Associada do Dept ${ }^{\mathrm{O}}$ Defesa Fitossanitária, UFSM. E-mail: marlovemuniz@yahoo.com.br

5 Enga Ftal, Doutoranda do Programa de Pós-graduação em Engenharia Florestal, UFSM. E-mail: alinerittercurti@yahoo.com.br

Autor para correspondência 
dormancy, mechanical scarification was the most efficient. The maximum in vitro germination was observed in the medium 1/4 MS. The maximum in vitro germination was observed in the medium $1 / 4$ MS. The mechanical scarification with sandpaper provides the highest germination rate, while the maximum in vitro germination is observed using $1 / 4 \mathrm{MS}$ medium.

Key words: Mechanical scarification, forestry specie, nutritive media

A bracatinga, Mimosa scabrella Bentham, é uma árvore da família Fabaceae, subfamília Mimosoideae, nativa do Brasil, ocorrendo desde Minas Gerais até o Rio Grande do Sul. Seu principal uso madeireiro é como lenha e carvão. Entretanto, a madeira roliça é muito procurada para escoras na construção civil e, principalmente, para compensados e caixotaria. Não obstante, pode ser empregada com sucesso no paisagismo, principalmente na arborização de ruas, além de ser útil na recuperação de áreas degradadas (LORENZI, 2002).

Suas sementes apresentam dormência causada pela impermeabilidade do tegumento à água, fator de ocorrência muito comum em leguminosas (Fabaceae) florestais, dentre as quais as subfamílias Caesalpinoideae e Mimosoideae (sendo esta última a subfamília que pertence a $M$. scabrella) são as que apresentam maior número de espécies com sementes dormentes (DUARTE, 1978). Alguns métodos têm sido testados para superar a dormência decorrente da impermeabilidade do tegumento, tais como embebição em água, imersão em água quente, escarificação com ácido sulfúrico concentrado, escarificação mecânica, entre outros (RIBEIRO; BRAZ; BRITO, 2009). Em Schizolobium amazonicum Huber ex Ducke (Fabaceae - Caesalpinioideae), por exemplo, pode-se superar a dormência das sementes pela escarificação utilizando esmeril elétrico ou lixa (CRUZ; CARVALHO, 2006).

Os meios nutritivos usados na cultura de tecidos, quanto aos nutrientes, baseiam-se nas exigências de crescimento e desenvolvimento das plantas, com algumas modificações para atender às necessidades específicas das condições in vitro (SOUZA; JUNGHANS, 2006). A composição dos meios de cultura utilizados na micropropagação varia de acordo com a espécie e às diferentes etapas do processo, ou seja, estabelecimento, multiplicação e enraizamento in vitro. De maneira geral, emprega-se um meio básico composto de macro e micronutrientes, vitaminas, inositol, fonte de açúcar (geralmente sacarose) e, eventualmente, outros compostos orgânicos (como aminoácidos) que são suplementados com reguladores de crescimento.

A formulação conhecida como meio MS (MURASHIGE; SKOOG, 1962) é a mais utilizada para diferentes processos de cultura de tecidos, incluindo a micropropagação (GRATTAPAGLIA; MACHADO, 1998). Entretanto, para muitas espécies lenhosas, o meio MS não tem se mostrado satisfatório e composições mais diluídas apresentam melhor desempenho, assim como o uso de meios desenvolvidos para espécies lenhosas, como o Wood Plant Medium (WPM) (LLOYD; MCCOWN, 1981). A exemplo do uso de concentrações iônicas reduzidas no cultivo de espécies perenes, podese citar que meios de cultura MS e 1/2 MS foram eficientes na germinação in vitro de sementes e formação de plântulas normais de mangabeira (Hancornia speciosa Gomes). Entretanto, o meio de cultura MS com metade da concentração salina proporcionou $100 \%$ de germinação e bom desenvolvimento in vitro da parte aérea e sistema radicular das plântulas (LÉDO et al., 2007). É válido salientar que o meio também foi suplementado com carvão ativado.

Neste trabalho, os objetivos consistiram em selecionar um método de superação de dormência das sementes e estabelecer a concentração de sais do meio MS mais adequada à germinação in vitro de Mimosa scabrella Bentham.

As sementes foram coletadas de árvores 
matrizes em Itaara, RS, em dezembro de 2006, e permaneceram armazenadas em câmara fria (10$12{ }^{\circ} \mathrm{C}$ e UR\% de 35-40) durante todo o período de realização dos experimentos, de agosto de 2007 a dezembro de 2008.

Os tratamentos de superação de dormência utilizados neste trabalho consistiram de escarificação mecânica do lado oposto ao embrião com o auxílio de lixa Norton $\mathrm{n}^{\circ}$ 80; imersão em água à temperatura ambiente por 24 horas; imersão em água quente $\left(80^{\circ} \mathrm{C}\right)$ por cinco minutos; e testemunha. $\mathrm{O}$ delineamento utilizado foi $\mathrm{o}$ inteiramente casualizado, com quatro repetições, cada uma contendo 50 sementes.

As sementes foram colocadas sobre três folhas de papel filtro previamente umedecidas com água destilada até atingir 2,5 vezes a massa do papel seco, e acondicionadas em caixas plásticas tipo "gerbox". Na sequência, as unidades experimentais foram mantidas em germinador do tipo $\mathrm{BOD}$ regulado à temperatura de $25^{\circ} \mathrm{C}$ e fotoperíodo de 12 horas. Aos sete dias, foi avaliada a porcentagem de germinação com base no número de plântulas normais, e, aos 14 dias, as porcentagens de plântulas anormais, de sementes firmes e mortas. As avaliações foram baseadas nas recomendações prescritas nas Regras para Análise de Sementes (BRASIL, 2009), considerando-se como plântulas normais as sementes germinadas que desenvolveram todas as suas estruturas essenciais (especialmente raiz primária, epicótilo e cotilédones), demonstrando, assim, sua aptidão para produzirem plantas normais sob condições favoráveis de campo. Foram consideradas plântulas anormais aquelas que não demonstraram potencial para continuar seu desenvolvimento e dar origem às plântulas normais, por apresentarem-se danificadas (sem alguma estrutura fundamental), deformadas e/ou deterioradas (atacadas por patógenos). Considerou-se como sementes duras aquelas que não absorveram água e apresentaram-se, ao final do teste, com aspecto enrijecido. Classificou-se como sementes mortas aquelas que, ao final do teste, encontravam-se úmidas, com aspecto macio e, em alguns casos, atacadas por microorganismos, muitas vezes emitindo secreções com aspecto purulento (BRASIL, 2009).

Para avaliar a melhor concentração salina do meio de cultura na germinação de bracatinga, as sementes utilizadas neste trabalho foram submetidas ao processo de escarificação mecânica na região oposta ao eixo embrionário, com o auxílio de lixa Norton $n^{\circ} 80$, objetivando-se a superação da dormência. A seguir, para a desinfestação superficial, foram imersas em etanol a 70\% (v/v) durante 1 minuto. Logo após este período, seguiu-se o processo de desinfestação imergindo-se as sementes em solução de hipoclorito de sódio $(\mathrm{NaOCl})$ a 2,5\% (v/v) contendo três gotas de detergente comercial, por 15 minutos sob agitação constante. Ao final deste período, realizou-se um triplo enxágue em água destilada estéril.

O delineamento experimental utilizado foi o inteiramente casualizado com 25 repetições por tratamento, sendo que cada repetição consistiu de um frasco com capacidade para $150 \mathrm{ml}$ contendo 30 $\mathrm{ml}$ de meio nutritivo e três sementes. Os tratamentos consistiram de quatro concentrações de sais do meio de cultura MS (MURASHIGE; SKOOG, 1962): $1 / 8,1 / 4,1 / 2$ e concentração integral (100\%). O meio foi suplementado com ágar $\left(7 \mathrm{~g} \mathrm{~L}^{-1}\right)$, sacarose $\left(30 \mathrm{~g} \mathrm{~L}^{-1}\right)$ e teve o seu $\mathrm{pH}$ ajustado para 5,7. Antes da inoculação das sementes a qual ocorreu câmara de fluxo laminar, os frascos contendo os tratamentos foram esterilizados em autoclave por 15 minutos a $121^{\circ} \mathrm{C}$ e $1 \mathrm{~atm}$. As unidades experimentais foram mantidas em sala de cultivo com fotoperíodo de 16 horas obtido a partir de lâmpadas fluorescentes brancas frias tipo luz do dia, com intensidade luminosa de $20 \mu \mathrm{mol} \mathrm{m} \mathrm{m}^{-2} \mathrm{~s}^{-1}$ e temperatura de $25^{\circ} \pm 3^{\circ} \mathrm{C}$. Aos 25 dias de cultivo, avaliou-se a porcentagem de germinação das sementes in vitro.

Em ambos os experimentos, os dados obtidos foram transformadas para a função arco seno $\sqrt{X+0,5 / 100}$ e submetidos à análise de variância. 
Quando o valor de "F" foi significativo, para os tratamentos qualitativos utilizou-se o teste de Duncan a 5\% de probabilidade de erro, enquanto que, para os tratamentos quantitativos, utilizou-se a análise de regressão polinomial. Os dados expostos representam os originais. O programa estatístico utilizado foi o SANEST (ZONTA; MACHADO, 1986).

Dentre os métodos testados para superar a dormênciadas sementes debracatinga, a escarificação mecânica foi o mais eficiente, proporcionando os maiores percentuais de germinação e diferindo significativamente dos demais tratamentos (Tabela 1). Este fato demonstra que há uma barreira física nas sementes, a qual restringe a difusão de água até o embrião e a ativação de metabólitos e solubilização de nutrientes presentes no endosperma. Assim, a entrada de água só é efetivada quando ocorre o rompimento mecânico do tegumento.

Tabela 1. Efeito de diferentes tratamentos de superação de dormência na germinação (\%), aos sete dias após semeadura, e plântulas anormais (\%), sementes duras (\%) e sementes mortas (\%) de Mimosa scabrella Bentham, aos 14 dias de semeadura.

\begin{tabular}{lcccc}
\hline Tratamento & $\begin{array}{c}\text { Germinação } \\
(\%)\end{array}$ & $\begin{array}{c}\text { Plântulas } \\
\text { anormais }(\%)\end{array}$ & $\begin{array}{c}\text { Sementes duras } \\
(\%)\end{array}$ & $\begin{array}{c}\text { Sementes mortas } \\
(\%)\end{array}$ \\
\hline Testemunha & $36,0 \mathrm{~b}^{*}$ & $2,5 \mathrm{a}$ & $32,5 \mathrm{~b}$ & $15,0 \mathrm{~b}$ \\
Escarificação mecânica & $88,0 \mathrm{a}$ & $5,0 \mathrm{bc}$ & $0,0 \mathrm{a}$ & $7,0 \mathrm{a}$ \\
Imersão em água à temperatura ambiente & $34,5 \mathrm{~b}$ & $6,0 \mathrm{c}$ & $29,0 \mathrm{~b}$ & $26,5 \mathrm{c}$ \\
Imersão em água quente & $65,0 \mathrm{~b}$ & $4,5 \mathrm{~b}$ & $0,0 \mathrm{a}$ & $28,0 \mathrm{c}$ \\
\hline Média & 55,9 & 4,5 & 15,8 & 19,1 \\
CV $(\%)$ & 21,8 & 12,7 & 16,8 & 18,5 \\
\hline
\end{tabular}

*Médias seguidas pelas mesmas letras não diferem significativamente entre si pelo teste de Duncan ao nível de 5\% de probabilidade de erro.

Fonte: Elaboração dos autores.

Estes dados corroboram com os trabalhos de Santarém e Áquila (1995) com sementes de cássia (Senna macranthera (Colladon) Irwin \& Barnery), também da família Leguminosae. Os autores apontaram a escarificação mecânica como um dos tratamentos pré-germinativos mais eficientes para romper a dormência estrutural em sementes dessa espécie quando recém-coletadas e com um ano de armazenamento. Resultados semelhantes também foram observados por Martins et al. (2001), em que a escarificação mecânica com lixa $n^{\circ} 200$ revelou-se o melhor tratamento para a superação de dormência em sementes de Mimosa scabrella Bentham, seguido da imersão em água quente $\left(80^{\circ} \mathrm{C}\right)$ por quatro minutos.

A porcentagem de sementes duras observada após a escarificação mecânica e a imersão em água quente foi nula, diferindo significativamente dos valores observados nos demais tratamentos (Tabela 1). Contudo, deve-se destacar que a escarificação mecânica resultou em um menor percentual de sementes mortas comparada à imersão em água quente, e até mesmo em relação à testemunha, indicando ser um método promissor na superação de dormência das sementes de bracatinga. Já para a variável plântulas anormais, não houve efeito significativo dos métodos de superação de dormência avaliados (Tabela 1). Pode-se depreender disto que a escarificação das sementes, independentemente do método empregado, não acarretou em aumento na formação de anormalidades.

A máxima germinação in vitro de sementes de Mimosa scabrella Bentham foi observada na concentração de sais 1/4 MS (Figura 1) que, 
em conjunto com o meio MS reduzido a 1/8, da concentração integral dos sais do meio MS, forneceu mais água para promover esse processo. juntamente com a sacarose, pode ter afetado A partir de 1/2 MS, iniciou-se um decréscimo na o balanço osmótico, prejudicando o processo germinação, atingindo o valor mínimo no meio MS com concentração integral de sais. O emprego germinativo.

Figura 1. Efeito das diferentes concentrações de sais do meio nutritivo MS sobre a germinação de sementes de Mimosa scabrella Bentham aos 25 dias de cultivo in vitro.

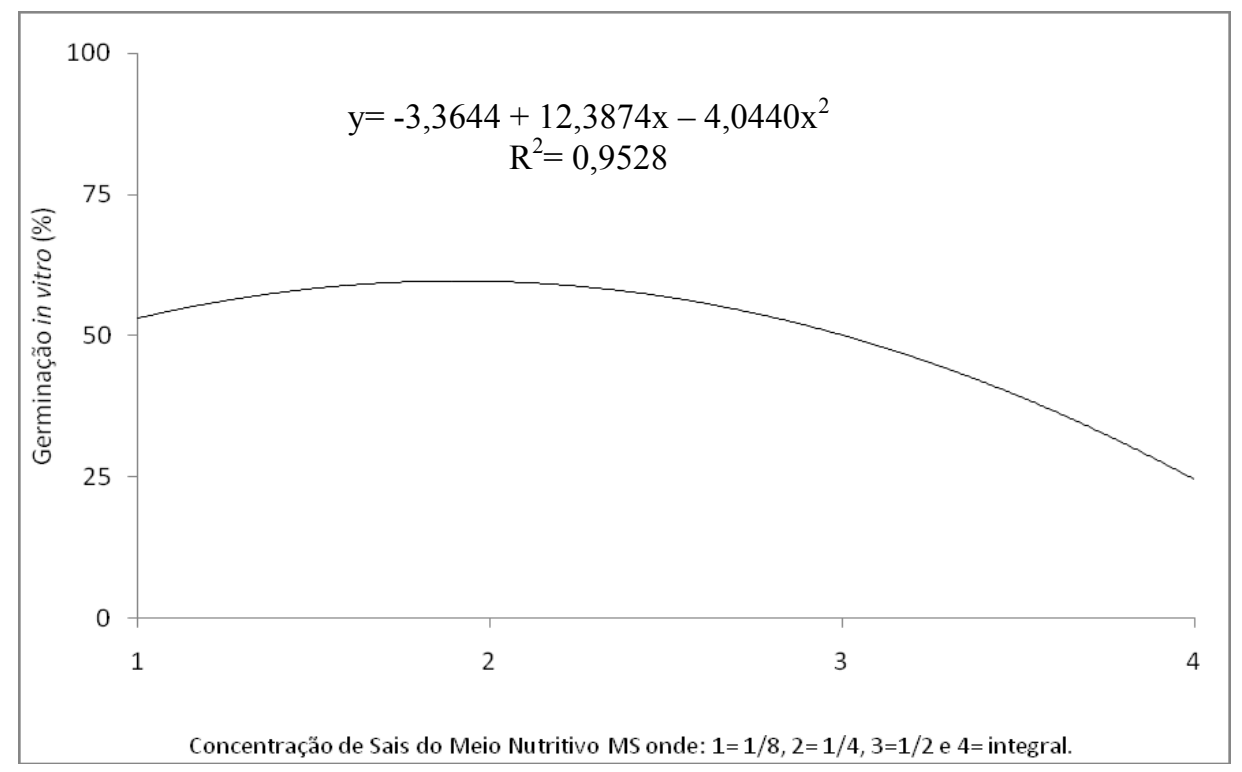

Fonte: Elaboração dos autores.

$\mathrm{O}$ meio $\mathrm{MS}$ reduzido à metade das concentrações de sais (1/2 MS) e na presença de sacarose acarretou em aumento na taxa de germinação de sementes de Byrsonima intermedia A. Juss. A redução da concentração dos sais parece ter compensado a adição de sacarose, não afetando, assim, o balanço osmótico e sendo favorável à germinação das sementes (NOGUEIRA et al., 2004). É válido destacar que a diminuição de sais nos meios de cultura é uma tendência mundial e muitas pesquisas estão sendo realizadas com esta finalidade. Não há uma formulação padrão, mas o meio MS, suas modificações e diluições têm apresentado bons resultados para as diversas espécies (CHAVES; SCHUCH; ERIG, 2005). Além disso, reduzir a concentração salina é satisfatório também do ponto de vista econômico.
Desta forma, pode-se concluir que a escarificação mecânica, efetuada com lixa, é um método eficiente para a superação da dormência em sementes de Mimosa scabrella Bentham, resultando em uma maior porcentagem de germinação. Além disso, a germinação in vitro de sementes de Mimosa scabrella Bentham é otimizada pelo cultivo em meio de cultura MS reduzido a 1/4 da concentração de sais.

\section{Agradecimentos}

À FEPAGRO (Fundação Estadual de Pesquisa Agropecuária, Unidade Florestas, Santa Maria, RS) pelo lote de sementes cedido aos experimentos e à CAPES (Coordenação de Aperfeiçoamento de Pessoal de Nível Superior) pelos recursos financeiros. 


\section{Referências}

BRASIL, Ministério da Agricultura, Pecuária e Abastecimento. Regras para análise de sementes. Ministério da Agricultura, Pecuária e Abastecimento. Secretaria de Defesa Agropecuária. Brasília: Mapa/ACS, 2009. $399 \mathrm{p}$.

CHAVES, A. C.; SCHUCH, M. W.; ERIG, A. C. Estabelecimento e multiplicação in vitro de Physalis peruviana L. Ciência e Agrotecnologia, Lavras, v. 29, n. 6, p. 1281-1287, 2005.

CRUZ, E. D.; CARVALHO, J. E. U. Methods of overcoming dormancy in Schizolobium amazonicum Huber ex Ducke (Leguminosae - Caesalpinioideae) seeds. Revista Brasileira de Sementes, Pelotas, v. 28, n. 3, p. 108-115, 2006.

DUARTE, A. P. Contribuição ao conhecimento da germinação de algumas essências florestais. Rodriguésia, Rio de Janeiro, v. 30, n. 45, p. 439-446, 1978.

GRATTAPAGLIA, D.; MACHADO, M. A. Micropropagação. In: TORRES, A. C.; CALDAS, L. S.; BUSO, J. A. (Ed.). Cultura de tecidos e transformação genética de plantas. Brasília: Embrapa-SPI/EmbrapaSNPH, 1998. v. 1, p. 183-260.

LÉDO, A. S.; SECA, G. S. V.; BARBOZA, S. B. S. C.; SILVA JÚNIOR, J. F. S. Crescimento inicial de mangabeira (Heincornia speciosa Gomes) em diferentes meios de germinação in vitro. Ciência e Agrotecnologia, Lavras, v. 31, n. 4, p. 989-993, 2007.

LLOYD, G.; McCOWN, B. Commercially feasible micropropagation of mountains laurel, Kalmia latifolia by use of shoot tip culture. Combined Proccedins International Plant Propagators Society, Washington, v. 30, p. 327-421, 1981.
LORENZI, H. Árvores brasileiras: manual de identificação e cultivo de plantas arbóreas nativas do Brasil. 4. ed. São Paulo: Odessa/Instituto Plantarum, 2002. v. 1,368 p.

MARTINS, C. C.; SENEME, A. M.; MORI, E. S.; NAGAKAWA, J.; CAVARIANI, C. Métodos de superação de dormência em sementes de bracatinga (Mimosa scabrella). Informativo ABRATES, Brasília, v. 11, n. 2, p. 250, 2001.

MURASHIGE, T.; SKOOG, F. A Revised medium for rapid growth and bio-assays with tobacco tissue cultures. Physiologia Plantarum, Copenhagen, v. 15, n.1, p. 437496, 1962.

NOGUEIRA, R. C.; PAIVA, R.; CASTRO, A. H. de; VIEIRA, V. V.; ABBADE, L. C.; ALVARENGA, A. A. Germinação in vitro de murici-pequeno (Byrsonima intermedia A. Juss). Ciência e Agrotecnologia, Lavras, v. 28, n. 5, p. 1053-1059, 2004.

RIBEIRO, V. V.; BRAZ, M. S. S.; BRITO, N. M. Tratamentos para superar a dormência de sementes de tento. Biotemas, Florianópolis, v. 22, n. 4, p. 25-32, 2009.

SANTARÉM, E. R.; ÁQUILA, M. E. A. Influência de métodos de superação de dormência e do armazenamento na germinação de sementes de Senna macranthera (COLLADON) IRWIN \& BARNERY (LEGUMINOSAE). Revista Brasileira de Sementes, Brasília, v. 17, n. 2, p. 205-209, 1995.

SOUZA, A. S.; JUNGHANS, T. G. Introdução à micropropagação de plantas. Cruz das Almas, BA: Embrapa Mandioca e Fruticultura Tropical, 2006. 152 p.

ZONTA, E. P.; MACHADO, A. A. Sistema de análise estatística para microcomputadores - SANEST. Pelotas: Instituto de Física e Matemática, IFM, UFPel, 1986. 90 p. 